WJWL \#903709, VOL 0, ISS 0

\title{
LibGuides and Web-Based Library Guides in Comparison: Is There a Pedagogical Advantage?
}

\author{
AARON BOWEN \\ QUERY SHEET
}

This page lists questions we have about your paper. The numbers displayed at left can be found in the text of the paper for reference. In addition, please review your paper as a whole for correctness.

There are no Editor Queries for this paper.

\section{TABLE OF CONTENTS LISTING}

The table of contents for the journal will list your paper exactly as it appears below:

LibGuides and Web-Based Library Guides in Comparison: Is There a Pedagogical Advantage?

Aaron Bowen 


\title{
LibGuides and Web-Based Library Guides in Comparison: Is There a Pedagogical Advantage?
}

\author{
AARON BOWEN \\ Meriam Library, California State University, Chico, California, USA
}

This study investigates whether the platform used to deliver a tutorial matters in online information literacy instruction and assesses the overall quality of an information literacy tutorial assignment given to an undergraduate survey class. The study asks whether there is any pedagogical advantage between information literacy tutorials created in the LibGuides library guide creation software and tutorials created as Web pages. This research question is relevant to current studies of online information literacy tutorials, particularly given the increasingly dominant but under-researched position of LibGuides in the academic library world for delivering guides and tutorials. Two separate groups of students completed LibGuides and Web page versions of the same information literacy tutorial assignment in a university undergraduate communication course. Survey results of these 89 students indicated that both the LibGuides and Web page platforms deliver online instruction content effectively and achieve learning objectives almost equally well. Results also indicated content areas within the assignment that could be strengthened.

KEYWORDS information literacy, LibGuides, Web page tutorials, online instruction, online tutorials, undergraduate students, pedagogy

(C) Aaron Bowen

Received 30 August 2013; accepted 13 October 2013.

Address correspondence to Aaron Bowen, Reference/Subject Librarian, Meriam Library, California State University, Chico, CA95929-0295. E-mail: asbowen@csuchico.edu 
Inspired by increasing interest among librarians from the 1970s onward in helping patrons become information literate, many university libraries now include pathfinders, guides, tutorials on using library services, and other created in-house and can be either general or discipline-specific. They frequently begin as scanned copies of paper guides.

The creation of these online IL instruction materials requires a certain degree of technological skill on the part of the librarian. It is not feasible for a library to give the assignment of digitizing and maintaining a variety of discipline-specific materials to one librarian, or to rely on the library Webmaster to handle the assignment. There has been an ongoing need among librarians to be able to create online guides while avoiding the learning curves associated with Web-based technologies.

This need is often filled by LibGuides, the primary proprietary guidecreation platform within the library world released by Springshare in 2007 (http://springshare.com/). Individual LibGuides pages are flexible in allowing libraries to include their own branding on guides' headers and in allowing librarians to customize content. They do, however, follow a uniform architecture, consisting of standardized header features: tabs, drop-down menus at the top of the screen, and either one, two, or three columns for content display. ${ }^{1}$ In contrast, with enough time and skill devoted to its design, an HTML or XML-based Web page can look however the librarian wants it to.

These two methods of designing Web-based library guides parallel each other in the contemporary library world. Does one method have any pedagogical advantage over the other, or do both methods achieve approximately the same results when instructing students on library use? To answer this question, two different versions of the same IL assignment were given to 25 sections of an undergraduate communication course at California State University Chico (CSU Chico) during the fall of 2012. One version of the assignment was created in LibGuides, and the other consisted of a series of Web pages.

For this study, the literature on LibGuides, online IL tutorials, and the methodologies used to assess them was reviewed. Following these summaries is a presentation of the methodology used in this study and the results of a tutorial assessment survey. This article concludes with a discussion of those results, including a comparison of the survey results gathered using the two tutorial platforms, a discussion of the strengths and weaknesses of the tutorial assignment itself as well as a plan for strengthening it, and a discussion of future research directions. 
72

\section{IL Definitions and Standards}

The emergence of IL in university education has created broad initiatives to define and standardize the concept. These initiatives include, among others, the ACRL Information Literacy Competency Standards for Higher Education (2000).

The ACRL standards (2000, para. 1) define IL as "a set of abilities to 'recognize when information is needed and have the ability to locate, evaluate, and use effectively the needed information." These standards further present IL as enabling a person to do the following:

89 - Determine the extent of the information needed;

- Access the needed information effectively and efficiently;

- Evaluate information and its sources critically;

- Incorporate selected information into one's knowledge base;

- Use information effectively to accomplish a specific purpose; and

- Understand the economic, legal, and social issues surrounding the use of information, and access and use information ethically and legally. (para. 2)

While there are individual differences between the definitions and standards set forth in the other initiatives, they all generally embody the same points as those presented by ACRL.

These initiatives have informed many of the online IL tutorials that came into existence during the 2000s. Bradley Brazzeal (2006), for example, discussed applying initiatives to online research guides in general. Ada Emmett and Judith Emde (2007) specifically analyzed the application of the ACRL standards to IL assessment. 


\section{IL Assessment}

Lorrie Knight (2002) offered a compelling summary of why IL assessment is of value to libraries and universities: It supports a university's ability to be accountable for student learning (thus fulfilling its accreditation requirements), and it demonstrates that the library has developed a metric for measuring IL among students, that the library is functionally instructing these students on the principles of IL, and that the library is able to improve its instruction as needed. Debra Gilchrist and Anne Zald (2008) presented a methodology for applying these principles to a university's IL instruction in a practical and replicable manner.

Andrew Walsh (2009) wrote an extensive review of different methods used in assessing IL tutorials' efficacy in teaching students to be information literate. He found that many assessment methods drawing from constructivist pedagogy involve multiple choice questionnaires or short answer quizzes, though other methods included having students create portfolios, write essays, analyze bibliographies, or participate in simulation activities. Beyond these assessment mechanisms, Walsh mentioned two studies in which librarians observed students as they completed library search tasks and ten studies that incorporated self-assessment into the data gathered from students. Walsh did not treat these methodologies as mutually exclusive to each other, reflecting the fact that some methodologies were combined in individual studies.

Walsh did not address the most common construction of such assessment: the pretest/posttest construction, whereby students take a short quiz before beginning an IL tutorial and then retake the quiz after the tutorial to see if their research abilities improved. Carol McCulley (2009) and Kornelia Tancheva, Camille Andrews, and Gail Steinhart (2007) examined this construction. Both studies reviewed different assessment strategies, and described mixing these strategies together to forge an understanding of what their respective IL instruction programs do and where they need adjustment to further student learning. McCulley employed pre- and posttests, engaged in informal classroom observations and discussions with students, and included performance assessments such as short classroom presentations and annotated bibliographies in her assessment. Tancheva and colleagues did much the same thing, using pre- and posttests, focus groups, and Web-based surveys. Both articles measured knowledge-based and affective methods to assess student learning: measurements of whether or not a student learned and retained assignment content, and whether or not a student believed the assignment achieved its objectives. Tancheva and colleagues also used a third measure to assess gaps between instructor and student perceptions of IL comprehension. Judy Bell (2011) offered an in-depth examination of affective student assessment. These measures form the basis of the methodology used in this research project. 
While the bulk of the literature on IL discusses assessment, following the lead of Nancy Dewald (1999) in particular, a smaller but still significant number of articles have discussed assessment of online tutorials, specifically via university-developed tutorials (Tooman and Sibthorpe 2012; Friehs and Craig 2008; Ivanitskaya et al. 2008; Zoellner, Samson, and Hines 2008).

Four studies (Su and Kuo 2010; Somoza-Fernández and Abadal 2009; Yang 2009; Lindsay et al. 2006) offered comparisons of different tutorials. Nancy Noe and Barbara Bishop (2005) assessed Auburn University's implementation of the Texas Information Literacy Tutorial (TILT), and Irvin Katz (2007) evaluated iSkills, the forerunner of iCritical Thinking, a product of the Educational Testing Service. Furthermore, there exists a non-institutionspecific inventory called Project SAILS, which some libraries have employed to assess their IL tutorials (Rumble and Noe 2009). Yvonne Mery, Jill Newby, and Ke Peng (2011) created an in-house instrument based upon SAILS, while Cara Bradley and Leeanne Romane (2007) adapted SAILS to evaluate their local implementation of TILT.

The IL tutorial assignment evaluated in this study was based upon elements of the ACRL Standards. In terms of assessment, this study drew on existing IL assessment models operating on both the knowledge-based and affective measurement logics described by McCulley and Tancheva and colleagues. The knowledge-based questions were modeled on those developed by Mery and colleagues and were evaluated by three librarians for validity. The questions corresponded to different ACRL (2000) standards.

\section{LibGuides}

As noted previously, barriers to placing library guides online (requiring certain technical and Web design skills, maintaining the currency and relevance of online guides, and employing generic tutorials such as TILT) have led to the desire for more efficient methods of placing library guides online. LibGuides has emerged during the past four years to offer librarians a simple, fast, and easy-to-use platform for creating online learning content. As of now, over 60,000 librarians have used LibGuides to create online learning content (Springshare 2013). LibGuides has become the primary proprietary platform for guide creation within the library world (a position aided by the lack of direct competitors). Donald Moses and Jennifer Richard (2008) noted SubjectsPlus as a competitor, and Oregon State University developed Library à la Carte, but being open source, these two platforms have substantially different dynamics from LibGuides in terms of how a library would host and maintain them. No other proprietary products have entered the market to compete with LibGuides. 
LibGuides combines the popularity of modular IL instruction with the desire to create, adapt, or reuse tutorials (or elements of tutorials) with ease, just as librarians would do with TILT. LibGuides also offers substantial technical advantages over Web-based tutorials. It is, for example, easier to embed instruction videos in LibGuides and share content between LibGuides than it is to perform these tasks with Web pages.

Despite its popularity, there is sparse research on how university students use LibGuides and what benefits it affords them. Jacqueline Solis and Ellen Hampton (2009) mentioned LibGuides in passing, as if acknowledging that no research on the product had been conducted at that time. Since then, a flurry of articles have been published describing the implementation and use of LibGuides in libraries (Mokia and Rolen 2012; Gerberi, Hawthorne, and Larsen 2012; Roberts and Hunter 2011; Adebonojo 2010; Daly 2010; Glassman and Sorensen 2010; Gonzalez and Westbrock 2010; McMullin and Hutton 2010; Miner and Alexander 2010), but these articles offer little to no assessment of the value derived from these guides. ${ }^{2}$ Amy Gustavson, Angela Whitehurst, and David Hisle (2011) began filling this gap in the literature by measuring students' responses to an IL tutorial presented in modular fashion via LibGuides. Karen Neves and Sarah Jane Dooley (2011) further filled this gap by examining the correlation between medical topics taught over the course of a semester and topics presented on their library's LibGuides. Sarah Anne Murphy and Elizabeth Black (2013) and Aaron Bowen (2012) presented data on students' reactions to LibGuides embedded in learning management system environments.

While there is a significant body of literature assessing IL presented in Web-based tutorials, the field is still open for assessment regarding IL presented in LibGuides tutorials. Even accounting for the technical advantages possessed by LibGuides, it is unclear whether LibGuides offers any pedagogical advantage over Web pages (or vice versa), or if both platforms are approximately equal in terms of presenting IL tutorials. Only two studies have compared learning outcomes between platforms, both of which predate the introduction of LibGuides (Tempelman-Kluit 2006; Salisbury and Ellis 2003). Julie Robinson and Don Kim (2010) compared LibGuides to three sets of guides created individually by different librarians, but they did not discuss pedagogies or learning outcomes. As such, a comparison of pedagogical value between LibGuides and Web pages is a new area of research. 
The university's College of Communication and Education is divided into two departments: Communication Design and Communication Arts and Sciences. Communication Arts and Sciences further divides itself into two programs: Communication Studies and Communication Sciences and Disorders. CSU Chico's Communication Studies program offers a broad survey course called Small Group Communication (Communication 132), which attracts substantial numbers of first-year students. When this research was conducted during the fall 2012 semester, there were 812 students enrolled in the 25 sections of Communication 132.

As part of their coursework in Communication 132, students are required to participate in the Chico Great Debate, a day-long series of debates involving CSU Chico students and members of the public. The topic of the debate changes every semester, but it is always a controversial topic, and the preparation for the debate always involves a significant amount of library research.

\section{The Communication 132 Library Assignment}

Part of students' coursework in Communication 132 is tied into the Great Debate. The Communication 132 IL tutorial assignment introduces students to the concepts of IL. Before the library licensed LibGuides, the library assignment existed as a series of Web pages arranged in a linear progression. The six sections of the assignment involve the following tasks, drawn from the ACRL (2000) IL standards:

- Section one: Students identify keywords and main concepts in their presentation topic and arrange these keywords using Boolean operators.

- Section two: Students consider the process of distinguishing a scholarly work from a non-scholarly one and evaluating information for quality.

- Section three: Students search Academic Search for scholarly articles on their topic.

- Section four: Students search the library catalog for books on their topic.

- Section five: Students search for newspaper articles on their topic.

- Section six: Students prepare an annotated bibliography.

261 The Communication 132 instructors include a link to the page of instructions 262 for the assignment in their course materials (see Figure 1). This instruction 263 page leads first to a worksheet that students fill out as they progress through 264 the assignment and then successively through each of the assignment's six 265 sections.

266 Following CSU Chico's acquisition of LibGuides in 2009, the assignment 267 was updated and put into LibGuides form (see Figure 2). The objectives 268 of the assignment and much of its content remained the same, with the 


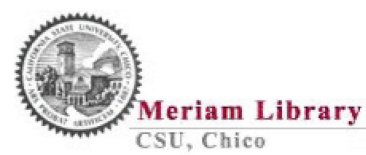

CSU, Chico

CALIFORNIA STATE UNIVERSITY, CHICO

\section{CMST 132}

Library Assignment

The purpose of this assignment is to help you find credible, high-quality sources using the Meriam Library that will be of value in giving Great Debate presentations, and to prepare a three-source list of references.

The first component of this assignment you will see is the assignment worksheet, which is at the bottom of this page following these instructions. Past the assignment worksheet, you will proceed through a series of webpages comprising the seven sections of the assignment. You must print out the assignment workseet, and then fill it out as you proceed through the assignment's pages.

4C/Art

\section{Assignment objectives:}

The assignment objectives are to:

- Identify keyword(s) or main concept(s) in your Great Debate topic.

- Search library resources to find relevant information while avoiding irrelevant or less useful information.

- Use the library catalog to find a book's call number, and then use the call number to locate the book in the Meriam Library.

- Write citations for the articles and book you find over the course of the assignment using the American Psychological Association (APA) citation style. The APA citation style is used by many academic fields, not just psychology.

The assignment is divided into seven sections:

- Section one: Developing your search. This section will allow you to identify one or more keywords or main concepts in your presentation topic and arrange these keywords in search strings using the words AND and $\mathrm{OR}$

- Section two: Understanding the process of distinguishing a scholarly work from a non-scholarly one, and of evaluating information for quality. This section is divided into two parts.

- Section three: Searching the Academic Search database for scholarly articles about your topic.

- Section four: Using the library catalog to search for books about your topic.

- Section five: Searching for a newspaper article. Though they are non-scholarly, newspasper articles can offer useful information about your topic.

- Section six: Preparing an Annotated Bibliography. This section will allow you to properly cite the sources you find and organize them in an annotated bibliography. You will also write an annotation (a short paragraph

FIGURE 1 Screenshot of a section of the Web page version of the assignment. (Color figure available online).

worksheet and its six sections. The most significant adjustment was to the architecture of the assignment's onscreen presentation: Rather than existing as a series of Web pages, the assignment's sections became a set of tabs at the top of the screen.

The primary purpose of the current research is to evaluate the extent to which an assignment presented in LibGuides holds any pedagogical advan- 


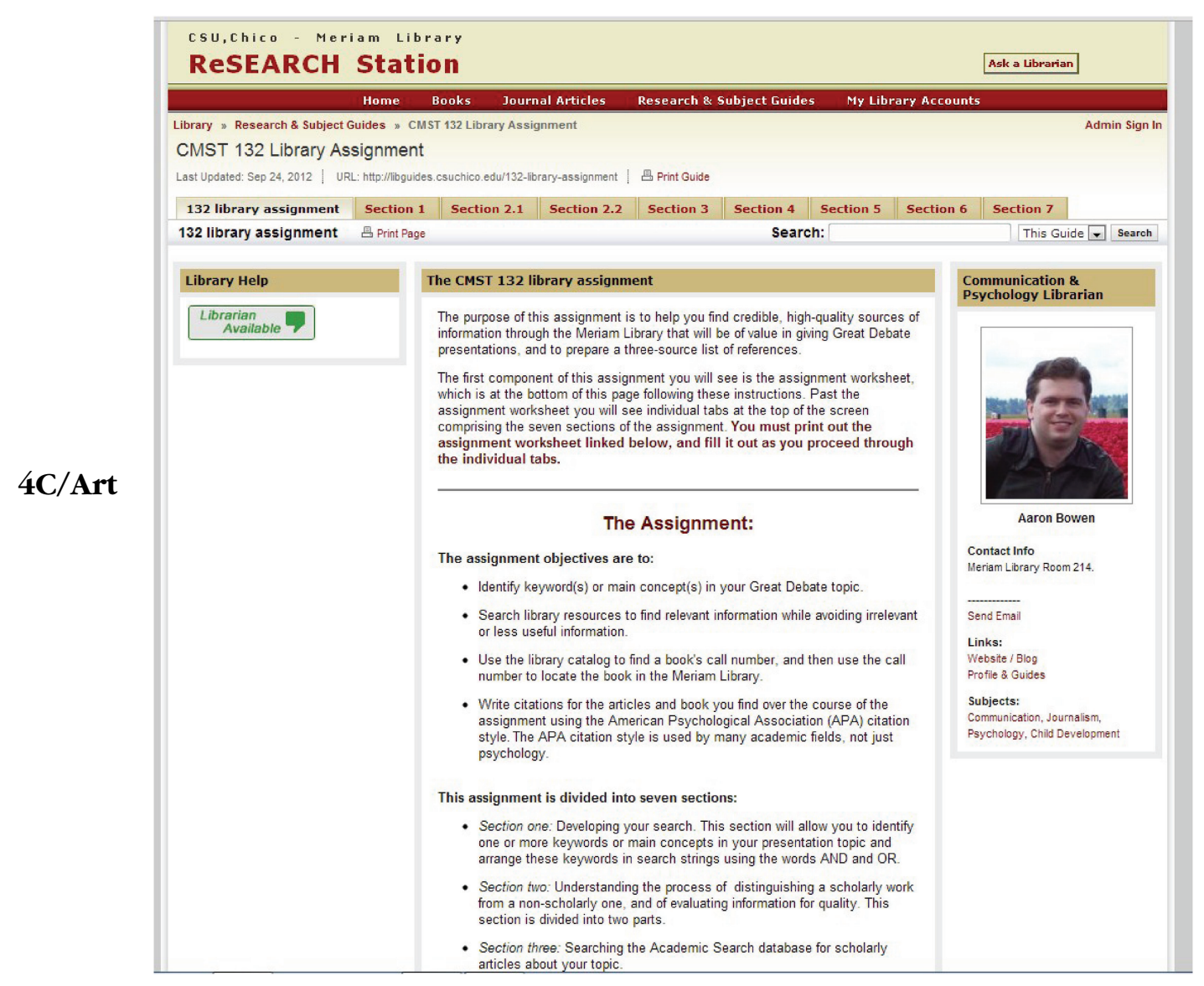

FIGURE 2 Screenshot of a section of the LibGuides version of the assignment. (Color figure available online).

original Web page version of the assignment was brought back and updated to reflect the current LibGuides version of the assignment. Each version of the assignment had a unique URL. A link to one of the two assignment platforms was included in the student coursework for all 25 sections of the course. The LibGuides version was seen by students in twelve sections of the course identified via randomly generated numbers between 1 and 25. The Web page version was seen by students in the remaining thirteen sections. In terms of instructional content, the assignment was identical between the two platforms.

\section{Experimental Setup}

For the purpose of conducting the current research, a seventh section was added to each version of the assignment, presenting students with a 
sixteen-question survey on the students' IL knowledge and their reactions to the assignment. More precisely, two duplicate versions of the survey, asking the same questions, were added to the respective versions of the assignment.

Drawing from the knowledge-based and affective measurement logics described by McCulley and Tancheva and colleagues, the survey began with six knowledge-based questions corresponding to each of the first six sections of the assignment. This set of questions was followed by five affective questions and then five demographic questions. Drafts of all eleven non-demographic survey questions and their responses were reviewed by three librarians. Over the course of several reviews, consensus developed as to which questions corresponded to different ACRL (2000) standards and which answer constituted the "best answer" to a question.

The first page of the survey consisted of a statement mandated by CSU Chico's Institutional Review Board that the survey was optional and had no effect on students' assignment grade. As students were not required to respond to the survey, many students decided to forego it. The survey completed by students who had the LibGuides version of the assignment received 53 responses, and the survey completed by students who had the Web page version received 36 responses. The 89 combined survey responses represented 11 percent of the total course enrollment.

Forty-seven of the 53 students who completed the survey from the LibGuides version of the assignment responded to the demographic questions, with the exception of the question on gender, which received 45 responses. Of these 45 , twelve were male ( 27 percent), and 33 were female (73 percent). Of the 47 who responded to the other questions, 94 percent were 18-20 years old, 79 percent were first-year students, and 91 percent were not communication majors.

Thirty-two of the 36 students who completed the survey from the Web page version of the assignment responded to the demographic questions. Of these 32 , seven were male ( 22 percent), and 25 ( 78 percent) were female. All respondents were 18-20 years old, and all but one were first-year students. Twenty-five (78 percent) were not majoring in communication.

Of the 79 total respondents to the survey's demographic questions using both platforms, nineteen (24.1 percent) were male, 58 (73.4 percent) were female, two (2.5 percent) did not indicate a sex, and 76 (96 percent) were 18-20 years old. Also of these 79, 68 (86 percent) were first-year students. Furthermore, only six ( 8 percent) of the 79 were majoring in communication, and none were minoring in communication.

\section{RESULTS}

\section{Knowledge-Based Survey Questions}

The six knowledge-based questions were modeled on those developed by Mery and colleagues, who created an in-house instrument based on Project SAILS. The percent correct for each question is shown in Table 1. 
TABLE 1 Percent Correct for Each of the Knowledge-Based Survey Questions

\begin{tabular}{lcccc}
\hline & $\begin{array}{c}\text { Number of } \\
\text { students } \\
\text { Question }\end{array}$ & $\begin{array}{c}\text { PibGuides } \\
\text { version }\end{array}$ & $\begin{array}{c}\text { Percent } \\
\text { version (total) } \\
\text { correct Web } \\
\text { page version }\end{array}$ & $\begin{array}{c}\text { Number of } \\
\text { students Web }\end{array}$ \\
(total)
\end{tabular}

The first of these six questions was designed to measure the student's knowledge of the beginning of the research process, specifically, the student's knowledge of forming a search string. It corresponds to the "Determine the extent of information needed ability" in the ACRL (2000) standards. The question read,
For your Great Debate research, you are considering researching the effects of the current economy in the U.S. on higher education. Choose the search string that you think would best locate resources on this subject:

- Effects and current and economy and higher and education and USA;

- Effects current economy higher education United States;

- The effects of the current economy on higher education in the United States;

- Effects and higher education and United States [best response]. 
In terms of which string would best locate resources, the second response was intended to be rejected as the best way to locate resources due to its lack of Boolean operators. Also to be rejected was the third response because of its use of natural language. Of the remaining two responses, "Effects and higher education and United States" was intended to be the correct answer, because it is the most concise. Thirty-nine percent of the students from the LibGuides group and 26 percent of students from the Web Page group chose the correct response. The remaining students' responses varied greatly, independent of platform use; at least six students from each group chose each of the other responses.

Responses to the next three questions garnered more uniform responses. Corresponding to the "Evaluate information and its sources critically" ability in the ACRL (2000) standards, the second survey question was designed to measure students' abilities to evaluate information critically with regard to selecting the most authoritative source. It read,

\begin{abstract}
You are searching for information on the economic impact of wind energy, and you need to find accurate, unbiased information. Which of the following Web sites would be the best resource? (You can view each link to get a better idea of the type of content each page produces):
\end{abstract}

- The Wikipedia page on wind power (http://en.wikipedia.org/wiki/Wind_ power);

- The U.S. Department of Energy homepage (http://www.eere.energy.gov/) [best response];

- The General Electric page on wind turbines (http://www.ge-energy.com/ wind);

- The Wall Street Journal editorial page (http://online.wsj.com/public/ page/news-opinion-commentary.html).

The U.S. Department of Energy homepage was correctly picked by most students using both platforms as having the most accurate and unbiased information. Students were generally able to identify the answer based upon their completion and comprehension of section two of the assignment, regardless of which version they saw.

The third, fourth, and fifth questions all correspond to the "Access the needed information effectively and efficiently" tenet of the ACRL (2000) standards. The third question concerned a student's ability to select the best source for finding a journal article: 
384

385

386

387

- A library database such as Academic Search [best response];

- Education.gov;

- The library catalog;

- LibraryArticles.org.

Most students answered this question correctly as well, regardless of platform.

Question four assessed a student's knowledge of how books are organized in the Meriam Library:

How are books arranged in the library?

- By call number [best response];

- By author;

- Alphabetically by title;

- By most current year.

The LibGuides version of the survey received a lower proportion of correct responses (78 percent) than the Web page version (91 percent).

The phrasing of question five appeared to challenge students, obscuring the measurement of pedagogical advantage. The question read,

\section{Wikipedia, an online encyclopedia}

- The Journal of International Relations, a scholarly journal;

- The U.S.-Mexican Border in the Twentieth Century, a book in the Meriam Library catalog;

- The New York Times, a newspaper [best response].

Only 32 percent of students using the LibGuides version answered correctly, while 17 percent of the students using the Web page version chose the correct response.

Question six revealed broad consensus on the correct response from both versions of the assignment. Corresponding to both the "Incorporate selected information into one's knowledge base" and the "Understand the economic, legal, and social issues surrounding the use of information, and access and use information ethically and legally" abilities in the ACRL (2000) standards, this question was designed to assess student recognition of a citation. The question read, 
Read the citation that follows. What conclusion can you come to? Morio, H., \& Buchholz, C. (2009). How anonymous are you online? Examining online social behaviors from a cross-cultural perspective. $A I \&$ Society, 23(2), 297-307. doi:10.1007/s00146-007-0143-0

- This is a primary source;

- This is a scholarly article [best response];

- This is a book chapter;

- This is a letter to an editor.

Seventy-four percent of the students using the LibGuides version answered correctly, while 68 percent of the students using the Web page version answered correctly.

\section{Affective Survey Questions}

In this section, survey respondents were presented with five questions designed to measure their affective response to different aspects of the assignment. The questions asked students to rate their experiences with these aspects on a four-point Likert scale. The first three questions asked students to rank the ease, clarity, and convenience with which they were able to conduct library research after having completed the assignment:

Having completed the 132 library assignment, please rate how easy or difficult you find the following aspects of conducting library research:

Having completed the 132 library assignment, please rate how clear or unclear you find the following aspects of conducting library research:

Having completed the 132 library assignment, please rate how convenient or inconvenient you find the following aspects of conducting library research:

Drawn from each of the assignment's six sections, the aspects the students were asked to rate were

- Identify keyword(s) or main concept(s) embodied in the Great Debate topic;

- Understand the distinction between scholarly and non-scholarly works;

- Search for and find relevant scholarly articles while avoiding non-scholarly, irrelevant, and/or less useful information;

- Use the library catalog to find a book's call number, and then use the call number to locate the book in the Meriam Library;

- Search for and find relevant newspaper articles; 
- Write an annotated bibliography, including APA citations, for the articles and books you find over the course of the assignment.

A response of "1" on the scale indicated that a student found the assignment very easy, very clear, or very convenient, whereas a response of " 4 " indicated a student found the assignment very difficult, very unclear, or very inconvenient. Table 2 shows the average responses tended toward easy, clear, and convenient for most aspects, and the responses of the LibGuides and Web page platform users were similar.

The final two affective questions employed the same six assignmentbased attributes but adjusted the criteria measured by the Likert scale. In the first of these questions, the scale measured the degree of increase in knowledge for each attribute. In the second, it measured the degree of increase in satisfaction with engaging in each attribute. The scale remained 1-4 for each question, ranging from "Very significant increase" to "No increase."

The two question prompts read,

Rate the extent to which your knowledge of different aspects of using the Meriam Library has increased from before you completed the 132 library assignment:

Rate the extent to which your satisfaction with different aspects of using the Meriam Library has increased from before you completed the 132 library assignment:

Each prompt was followed by the six assignment-based attributes. The attributes and average responses are presented in Table 3. Again, the responses across platforms were quite similar.

The results of the first knowledge-based question showed a need to adjust and clarify the portion of the assignment on selecting topical search terms. The existing design of the section explains Boolean operators and has students begin their research process by developing a search string. Revised content should expand upon this base to include strategies for thinking about topics within the Great Debate topic to form the basis of a research agenda, and strategies for considering potential topics before devising discussion operators and search strings.

Despite the pedagogical need to adjust the first section of the assignment, the survey results indicated that regardless of the platform used, students were confused about how to formulate search strings. 


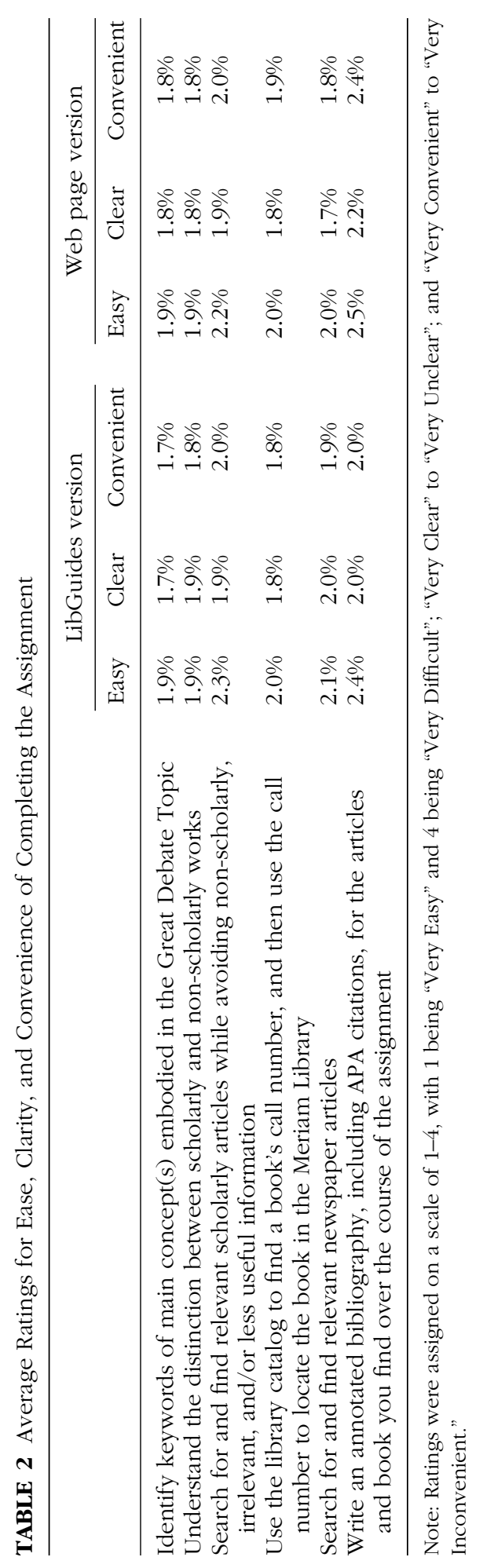


TABLE 3 Averages for the Questions on Knowledge of and Satisfaction with Using Library Resources

\begin{tabular}{|c|c|c|c|c|}
\hline & \multicolumn{2}{|c|}{ LibGuides version } & \multicolumn{2}{|c|}{ Web page version } \\
\hline & Knowledge & Satisfaction & Knowledge & Satisfaction \\
\hline $\begin{array}{l}\text { 1. Identify keyword(s) or main } \\
\text { concept(s) embodied in the Great } \\
\text { Debate topic }\end{array}$ & $2.0 \%$ & $2.1 \%$ & $2.2 \%$ & $2.1 \%$ \\
\hline $\begin{array}{l}\text { 2. Understand the distinction between } \\
\text { scholarly and popular works }\end{array}$ & $2.0 \%$ & $2.2 \%$ & $2.1 \%$ & $2.0 \%$ \\
\hline $\begin{array}{l}\text { 3. Search for and find relevant } \\
\text { scholarly articles while avoiding } \\
\text { non-scholarly, irrelevant, and/or } \\
\text { less useful information }\end{array}$ & $2.1 \%$ & $2.1 \%$ & $2.2 \%$ & $2.1 \%$ \\
\hline $\begin{array}{l}\text { 4. Use the library catalog to find a } \\
\text { book's call number, and then use } \\
\text { the call number to locate the book } \\
\text { in the Meriam Library }\end{array}$ & $2.0 \%$ & $2.0 \%$ & $2.2 \%$ & $2.2 \%$ \\
\hline $\begin{array}{l}\text { 5. Search for and find relevant } \\
\text { newspaper articles }\end{array}$ & $2.1 \%$ & $2.1 \%$ & $2.2 \%$ & $2.2 \%$ \\
\hline $\begin{array}{l}\text { 6. Write an annotated bibliography, } \\
\text { including APA citation, for the } \\
\text { articles and book you find over the } \\
\text { course of the assignment }\end{array}$ & $2.2 \%$ & $2.3 \%$ & $2.2 \%$ & $2.3 \%$ \\
\hline
\end{tabular}

Note: Ratings were assigned on a scale of $1-4$, with 1 being "Very significant increase" and 4 being "No increase."

The most common incorrect response to the third knowledge-based question was "the library catalog," indicating confusion about the differences between databases and the catalog. The confusion was roughly uniform between the two platforms; most students recognized the scholarly, authoritative resources and chose to search them (thus reinforcing section two of the assignment), but they had difficulties determining which academic resource searches what type of content. This finding parallels emerging research on discovery search systems such as EBSCO Discovery Service (Sarah Williams and Anita Foster 2011; Jody Fagan et al. 2012), which highlights the need for libraries to articulate the nuanced distinction between searching for articles in a database and for books in an online catalog.

The majority of the students responding to the fifth knowledge-based question seem to have overlooked the italicized word "current." Rather, they may have followed the principles presented in section two of the assignment and selected the most authoritative resource (choosing the book on the U.S.Mexican border because it is more specific to the topic than the Journal of International Relations, even though both are scholarly). If so, this question further reinforces the pedagogical success of section two of the assignment, especially in that the Wikipedia response attracted so little attention, even while obscuring measurement of the pedagogical success of section five across each platform. 
On the Web page version of the assignment, students chose the "book" response 63 percent of the time, as compared with 40 percent on the LibGuides version. It is unclear what caused this difference between the two versions of the assignment, specifically why the book was chosen as a substantially more attractive option than the others among the students using Web page version of the assignment, whereas this question elicited more mixed results from those who saw the LibGuides version. However, it is clear that despite the librarians' consensus on the question's phrasing and answer choices, the question must better emphasize currency as one of the factors in selecting a response. With this issue in mind, the question might be better written with a parenthetical:

When researching the border fence along the U.S. and Mexican border, which source would provide the most reliable current information (i.e., within the past three months)?

Including the publication date of the book (1999) would offer additional context for deciding which source is best for current information.

The first three affective questions revealed little difference between responses from either platform. For the question on ease of conducting library research, the responses and averages are similar for both respondent groups and indicate students' overall ease in completing the assignment, with the partial exception of sections three and six, which proved somewhat more challenging for students in each group. For the question on convenience, the averages are smaller numerically than the averages for the question on ease, demonstrating students on average found the assignment clearer than then they found it to be easy. Furthermore, despite a slightly greater variation in averages for the clarity of the newspaper question, the averages again show little variation between the students who completed the different versions of the assignments. The responses to the third question are also similar for each version of the assignment, with the exception of the averages with the final attribute, indicating a need for further explanation of annotations and APA citations in section six of the assignment.

While the responses to the first of the final two affective questions fell mostly into the "significant increase" category for both platforms, students using the LibGuides version did trend toward better success in learning the assignment's material. It is possible that the tabular construction of the LibGuides version provided clearer visual context, with the tabs for scholarly articles, books, and newspaper articles all visibly demarcated from each other, an idea paralleled by Kate Pittsley and Sara Memmott's findings (2012). This context may not have been as clear in the Web page version, which displayed the sections one at a time in linear fashion. In the second affective question, students expressed greater dissatisfaction with section six than with the rest of the assignment (LibGuides users' and Web page users' satisfaction 
indicators are both 2.3), reinforcing the finding that the assignment's explanation and task of creating an annotated bibliography requires adjustment and clarification.

The almost equal performances of survey respondents on the two versions of the assignment show the LibGuides and Web page platform differences were not a significant factor in student learning. In responding to the knowledge-based questions, users of both platforms were confused about the same concepts, while the majority of users were in agreement on correct choices and concepts. In responding to the affective questions, survey responses showed similarities in perceptions between the two groups.

As an IL tutorial, the Communication 132 assignment greatly improved students' understanding of the distinction between scholarly and nonscholarly sources, and their ability to search for articles and books. These successes were apparent in both groups; there were minimal differences reported in student abilities, with just slightly higher increases in IL skills and satisfaction among LibGuides platform survey respondents.

\section{Limitations and Future Directions}

Though the survey respondents represented a broad cross section of undergraduates from different majors at the beginning of their university career (and more critically, were not likely to be significantly different from their peers who did not complete the survey), the low response rate to the surveys may render the results ungeneralizable to other universities. As such, incorporating strategies to enhance the survey response rate, such as those discussed by Florian Keusch (2012); Jerold S. Laguilles, Elizabeth A. Williams, and Daniel B. Saunders (2011); Juan Sánchez-Fernández, Francisco MuñozLeiva, and Francisco Javier Montoro-Ríos (2011); and Dirk Heerwegh (2006), would benefit future assessment of the Communication 132 assignment, both by improving the response rate and by extension, determining whether or not the respondents are generalizable to the total student enrollment in the class.

Following from the research design proposed by Mery and colleagues, this study would further benefit from additional survey questions to draw from when conducting its knowledge-based assessment. Questions could be pretested with students to minimize the prospect of student error caused by question design. Also, multiple semesters of data collection could better support the reliability of the scores and the validity of the question pool. To this end, the Meriam Library is clarifying sections of the assignment that caused student confusion and is developing further assessment questions.

In terms of content design and phrasing of the questions, this study will help the Meriam Library improve the assignment. The sections on forming a search statement and on writing an annotated bibliography in particular will 
benefit from the creation of new content. Two librarians are developing a stand-alone guide to writing annotated bibliographies.

Other revisions and enhancements following from these observations include placing a site map on each page of the tutorial assignment and making the individual elements of the pages easy to find, similar to Roy Degler and colleagues' recommendations (2012). Both parts of the current section two are switching places with the current section one. With this switch, students will encounter the material about critically evaluating sources before they encounter the section on selecting a research topic and forming a search statement. The newspaper section will include selected news content relating to the Great Debate topic delivered via RSS feed. Plans are underway to design and record a series of Meriam Library-specific IL videos for the 132 assignment as well as other IL assignments at CSU Chico.

A new feature of the IL online instruction landscape, discovery software such as EBSCO Discovery Service (EDS), blurs the distinction between searching for articles and searching for books. This blurring must be addressed in current and future IL instruction, as it will only continue to gain salience within the academic library world. To this end, the Meriam Library is developing an instructional video on EDS and redesigning sections three and four of the 132 assignment to incorporate the video and other EDS-related content, a modification that will also be useful in updating other assignments and tutorials within the library.

The pool of knowledge-based questions will continue to be expanded and tested. Where testing reveals that a question is unclear or requires modification, such as with the current news question in this study, the question will be adjusted. Such adjustments will enable the librarians in the Meriam Library to design questions with increased validity and reliability as they continue to assess the Communication 132 assignment and other library assignments at CSU Chico.

LibGuides fits well and has a role to play in the ongoing quest for quality online IL instructional content, though it is not the only element that adds to the quality of an online learning experience. From a technical standpoint, it certainly enables librarians to create online learning content with more ease than with static Web pages. Web pages can be customized to fit a librarian's preferences with enough work, but LibGuides greatly reduces the technical and temporal barriers to completing that work.

From a pedagogical standpoint, LibGuides has value, though not necessarily any more so than any other platform, including static Web pages. Regardless of platform, the survey results for both student user groups are 
positive overall. While the results suggest room for improvement in different components of the assignment, these improvements are not created by pedagogical differences between the two platforms considered in this research.

\section{ACKNOWLEDGEMENTS}

The author would like to acknowledge James Tyler, Marc Langston, and Sarah Blakeslee for their review of the survey questions.

After receiving both his MLIS and a master of arts in international studies at the University of Washington, Aaron Bowen has served as the communication, journalism, psychology, and child development librarian at California State University, Chico since 2007. His research interests include the delivery of online information literacy instruction, digital learning technologies, and e-book and digital textbook initiatives. He has presented extensively on and written one prior article about LibGuides (2012).

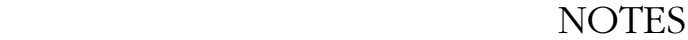

\footnotetext{
1. Springshare has announced that LibGuides will have the option of having a header box span content in multiple columns in 2014.

2. In addition to discussion of the implementation and use of LibGuides, other articles have analyzed unique aspects of the product or ways of using it. Kathryn Yelinek and colleagues (2010) described the process of replacing their main library homepage with LibGuides. Tony Stankus and Martha Parker (2012) compared and analyzed nursing LibGuides from fifty schools, concluding that there is a lack of a standard design practice for LibGuides due to individual librarians' preferences (and also presumably informed by individual university environments). Alec Sonsteby and Jennifer DeJonghe (2013) conducted a usability study on LibGuides at their university, and similar to Stankus and Parker, they concluded there is currently no consensus on a standard usability design of LibGuides. Susan Metcalf (2013) described using LibGuides as a collection development tool.
} ual Courses." College \& Undergraduate Libraries 17 (4):398-412. doi:10.1080/ 10691316.2010 .525426$.

Association of College and Research Libraries. 2000. "Information Literacy Competency Standards for Higher Education." Accessed August 29, 2013. www.ala.org/acrl/standards/Informationliteracycompetency.

Bell, Judy C. 2011. "Student Affect Regarding Library-Based and Web-Based Research before and after an Information Literacy Course." Journal of Librarianship $\varepsilon$ Information Science 43 (2):120-30. doi:10.1177/0961000610383634. 
Bowen, Aaron. 2012. "A LibGuides Presence in a Blackboard Environment." Reference Services Review 40 (3):449-68. doi:10.1108/00907321211254698.

Bradley, Cara, and Leeanne Romane. 2007. "Changing the Tire Instead of Reinventing the Wheel: Customizing an Existing Online Information Literacy Tutorial." College \& Undergraduate Libraries 14 (4):73-86. doi:10.1080/10691310802128344.

Brazzeal, Bradley. 2006. "Research Guides as Library Instruction Tools." Reference Services Review 34 (3):358-67. doi:10.1108/00907320610685319.

California State University, Chico. 2013. "Chico Facts." Accessed December 29, 2013. www.csuchico.edu/pa/chico-facts.shtml.

Daly, Emily. 2010. "Embedding Library Resources into Learning Management Systems: A Way to Reach Duke Undergrads at their Points of Need." College $\mathcal{E}$ Research Libraries News 71 (4):208-12. Accessed August 29, 2013. http://ehis. ebscohost.

Degler, Roy, Virginia Gravina, Fred Matofari, and Kathleen Kelsey. 2012. "LibGuides: User Perceptions, Expectations, \& Satisfaction." Paper presented at Internet Librarian, Monterey, CA, October 22.

Dewald, Nancy H. 1999. "Transporting Good Library Instruction Practices into the Web Environment: An Analysis of Online Tutorials." Journal of Academic Librarianship 25 (1):26-32.

Emmett, Ada, and Judith Emde. 2007. "Assessing Information Literacy Skills Using the ACRL Standards as a Guide." Reference Services Review 35 (2):210-29. doi:10.1108/00907320710749146.

Fagan, Jody C., Meris Mandernach, Carl S. Nelson, Jonathan R. Paulo, and Grover Saunders. 2012. "Usability Test Results for a Discovery Tool in an Academic Library." Information Technology \& Libraries 31 (1):83-112.

Friehs, Curt G., and Cindy L. Craig. 2008. "Assessing the Effectiveness of Online Library Instruction with Finance Students." Journal of Web Librarianship 2 (4):493-509. doi:10.1080/19322900802484438.

Gerberi, Dana, Dottie M. Hawthorne, and Karen E. Larsen. 2012. "Rethinking Responsible Literature Searching through LibGuides." Medical Reference Services Quarterly 31 (4): 355-71. doi:10.1080/02763869.2012.723981.

Gilchrist, Debra, and Anne Zald. 2008. "Instruction \& Program Design through Assessment." In Information Literacy Instruction Handbook, edited by C. N. Cox and E. B. Lindsay, 164-92. Chicago: Association of College and Research Libraries.

Glassman, Nancy R., and Karen Sorensen. 2010. "From Pathfinders to Subject Guides: One Library's Experience with LibGuides." Journal of Electronic Resources in Medical Libraries 7 (4):281-91. doi:10.1080/15424065.2010.529767.

Gonzalez, Alisa C., and Theresa Westbrock. 2010. "Reaching out with LibGuides: Establishing a Working Set of Best Practices." Journal of Library Administration 50 (5/6):638-56. doi:10.1080/01930826.2010.488941.

Gustavson, Amy, Angela Whitehurst, and David Hisle. 2011. "Laying the Information Literacy Foundation: A Multiple-Media Solution.” Library Hi Tech 29 (4):725-40. doi:10.1108/07378831111189796.

Heerwegh, Dirk. 2006. "An Investigation of the Effect of Lotteries on Web Survey Response Rates." Field Methods 18 (2):205-20. doi:10.1177/1525822X05285781.

Ivanitskaya, Lana, Susan DuFord, Monica Craig, and Anne Marie Casey. 2008. "How Does a Pre-Assessment of Off-Campus Students' Information Literacy 
Affect the Effectiveness of Library Instruction?" Journal of Library Administration 48 (3/4):509-25. Accessed August 29, 2013. http://condor.cmich. $\mathrm{edu} / \mathrm{cdm} / \mathrm{ref} /$ collection/p1610-01coll1/id/3131.

Katz, Irvin R. 2007. "Testing Information Literacy in Digital Environments: ETS's iSkills Assessment.” Information Technology \& Libraries 26 (3):3-12. doi:10.6017/ital.v26i3.3271.

Keusch, Florian. 2012. "How to Increase Response Rates in List-Based Web Survey Samples." Social Science Computer Review 30 (3):380-8. doi:10.1177/ 0894439311409709.

Knight, Lorrie A. 2002. "The Role of Assessment in Library User Education." Reference Services Review 30 (1):15-24. Accessed August 29, 2013. http://ehis.ebscohost.com. doi:10.1108/00907320210416500.

Laguilles, Jerold S., Elizabeth A. Williams, and Daniel B. Saunders. 2011. "Can Lottery Incentives Boost Web Survey Response Rates? Findings from Four Experiments.” Research in Higher Education 52 (5):537-53. doi:10.1007/s11162-010-9203-2.

Lindsay, Elizabeth B., Lara Cummings, Corey M. Johnson, and B. Jane Scales. 2006. "If You Build It, Will They Learn? Assessing Online Information Literacy Tutorials." College \& Research Libraries 67 (5):429-45. Accessed August 29, 2013. http://crl.acrl.org/content/67/5/429.full.pdf.

McCulley, Carol. 2009. "Mixing and Matching." Communications in Information Literacy 3 (2): 171-80. Accessed August 29, 2013. http://ehis.ebscohost.com.

McMullin, Rachel, and Jane Hutton. 2010. "Web Subject Guides: Virtual Connections across the University Community." Journal of Library Administration 50 (7/8):789-97. doi:10.1080/01930826.2010.488972.

Mery, Yvonne, Jill Newby, and Ke Peng. 2011. "Assessing the Reliability and Validity of Locally Developed Information Literacy Test Items." Reference Services Review 39 (1):98-122. doi:10.1108/00907321111108141.

Metcalf, Susan. 2013. "Good Stewards in Trying Times: Benchmarking Peer Collections of Sociology Reference Sources Using LibGuides." Reference Librarian 54 (2):134-42. doi:10.1080/02763877.2013.755423.

Miner, Jonathan, and Ross Alexander. 2010. "LibGuides in Political Science: Improving Student Access, Research, and Information Literacy." Journal of Information Literacy 4 (1):40-54. Accessed August 29, 2013. http://ehis.ebscohost.com. http://dx.doi.org/10.11645/4.1.1467.

Mokia, Rosemary, and Rhonda Rolen. 2012. "LibGuides: Improving Student and Faculty Access to Information Literacy." Codex: The Journal of the Louisiana Chapter of the ACRL 1 (4):37-45. Accessed November 8, 2013. http://journal.acrlla.org/index.php/codex/article/view/49/85.

Morio, Hiroaki, and Christopher Buchholz. 2009. "How Anonymous are You Online? Examining Online Social Behaviors from a Cross-Cultural Perspective." $A I$ E Society 23 (2):297-307. doi:10.1007/s00146-007-0143-0.

Moses, Donald, and Jennifer Richard. 2008. "Solutions for Subject Guides." Partnership: The Canadian Journal of Library \& Information Practice \& Research 3 (2):1-9. Accessed August 29, 2013. http://condor.lib.uoguelph.ca/ index.php/perj/article/view/907/1351\#.UlMAS1BebTo.

Murphy, Sarah Anne, and Elizabeth Black. 2013. "Embedding Guides Where Students Learn: Do Design Choices and Librarian Behavior Make a Difference?" 
The Journal of Academic Librarianship 23 (6):528-34. http://dx.doi.org/10. 1016/j.acalib.2013.06.007.

Neves, Karen M., and Sarah Jane Dooley. 2011. "Using LibGuides to Offer Library Service to Undergraduate Medical Students Based on the Case-Oriented Problem Solving Model." Journal of the Medical Library Association 99 (1):94-7. doi:10.3163/1536-5050.99.1.017.

Noe, Nancy W., and Barbara A. Bishop. 2005. "Assessing Auburn University Library's Tiger Information Literacy Tutorial (TILT)." Reference Services Review 33 (2):173-87. doi:10.1108/00907320510597372.

Pittsley, Kate A., and Sara Memmott. 2012. "Improving Independent Student Navigation of Complex Educational Web Sites: An Analysis of Two Navigation Design Changes in LibGuides." Information Technology and Libraries 31 (3):52-64. doi:10.6017/ital.v31i3.1880.

Roberts, Sara, and Dwight Hunter. 2011. "New Library, New Librarian, New Student: Using LibGuides to Reach the Virtual Student." Journal of Library \& Information Services in Distance Learning 5:67-75. doi:10.1080/1533290X.2011. 570552.

Robinson, Julie, and Don Kim. 2010. "Creating Customizable Subject Guides at Your Library to Support Online, Distance and Traditional Education: Comparing Three Self-Developed and One Commercial Online Subject Guide." Journal of Library \& Information Services in Distance Learning 4 (4):185-96. doi:10.1080/1533290X.2010.524830.

Rumble, Juliet, and Nancy Noe. 2009. "Project SAILS: Launching Information Literacy Assessment across University Waters." Technical Services Quarterly 26 (4):287-98. doi:10.1080/07317130802678936.

Salisbury, Fiona, and Jenny Ellis. 2003. "Online and Face-to-Face: Evaluating Methods for Teaching Information Literacy Skills to Undergraduate Arts Students." Library Review 52 (5):209-17. doi:10.1108/00242530310476715.

Sánchez-Fernández, Juan, Francisco Muñoz-Leiva, and Francisco Javier MontoroRíos. 2011. "Improving Retention Rate and Response Quality in WebBased Surveys." Computers in Human Behavior 28 (2):507-14. doi:10.1016/j. chb.2011.10.023.

Solis, Jacqueline, and Ellen M. Hampton. 2009. "Promoting a Comprehensive View of Library Resources in a Course Management System." New Library World 110 (1/2):81-91. doi:10.1108/03074S1910928603.

Somoza-Fernández, Marta, and Ernest Abadal. 2009. "Analysis of Web-Based Tutorials Created by Academic Libraries." Journal of Academic Librarianship 35 (2):126-31. Accessed August 29, 2013. http://dx.doi.org/10.1016/j.acalib. 2009.01.010.

Sonsteby, Alec, and Jennifer DeJonghe. 2013. "Usability Testing, User-Centered Design, and LibGuides Subject Guides: A Case Study." Journal of Web Librarianship 7 (1):83-94. doi:10.1080/19322909.2013.747366.

Springshare. 2013. "Our Community Sets Us Apart." Accessed August 29, 2013. http://www.springshare.com.

Stankus, Tony, and Martha A. Parker. 2012. "The Anatomy of Nursing LibGuides." Science \& Technology Libraries 31 (2):242-55. doi:10.1080/0194262X.2012. 678222 . 
Su, Shiao-Feng, and Jane Kuo. 2010. "Design and Development of Web-Based Information Literacy Tutorials." Journal of Academic Librarianship 36 (4):320-8. Accessed August 29, 2013. http://dx.doi.org/10.1016/j.acalib.2010.05.006.

Tancheva, Kornelia, Camille Andrews, and Gail Steinhart. 2007. "Library Instruction Assessment in Academic Libraries." Public Services Quarterly 3 (1/2):29-56. doi:10.1300/J295v03n01-03.

Tempelman-Kluit, Nadaleen. 2006. "Multimedia Learning Theories and Online Instruction." College \& Research Libraries 67 (4):364-9. Accessed August 29, 2013. https://files.nyu.edu/ntk2/public/multimedia.pdf.

Tooman, Camille, and Julie Sibthorpe. 2012. "A Sustainable Approach to Teaching Information Literacy: Reaching the Masses Online." Journal of Business \& Finance Librarianship 17 (1):77-94. doi:10.1080/08963568.2012.629556.

Walsh, Andrew. 2009. "Information Literacy Assessment: Where do We Start?" Journal of Librarianship \& Information Science 41 (1):19-28. doi:10.1177/ 0961000608099896.

Williams, Sarah C., and Anita K. Foster. 2011. "Promise Fulfilled? An EBSCO Discovery Service Usability Study." Journal of Web Librarianship 5 (3):179-98. doi:10.1080/19322909.2011.597590.

Yang, Sharon. 2009. "Information Literacy Online Tutorials: An Introduction to Rationale and Technological Tools in Tutorial Creation." Electronic Library 27 (4):684-93. http://dx.doi.org/10.1108/02640470910979624.

Yelinek, Kathryn, Linda Neyer, Darla Bressler, Michael Coffta, and David Magolis. 2010. "Using LibGuides for an Information Literacy Tutorial." College $\varepsilon$ Research Libraries News 71 (7):352-5.

Zoellner, Kate, Sue Samson, and Samantha Hines. 2008. "Continuing Assessment of Library Instruction to Undergraduates: A General Education Course Survey Research Project." College \& Research Libraries 69 (4):370-83. http://crl.acrl.org/content/69/4/370.full.pdf. 